\title{
CASUAL RELATION BETWEEN NUMBER OF TOURISTS AND EXCHANGE RATES: AN IMPLEMENTATION FOR TURKEY
}

DOI: 10.17261/Pressacademia.2020.1300

JBEF- V.9-ISS.3-2020(5)-p.245-252

\section{Rahmi Incekara}

Istanbul Kent University, Department of International Trade and Logistics, Istanbul, Turkey. rahmi.incekara@kent.edu.tr, ORCID ID. 0000-0001-8052-9315

To cite this document

Incekara, R., (2020). Casual relation between number of tourists and exchange rates: an implementation for Turkey. Journal of Business, Economics and Finance (JBEF), V.9(3), p.245-252.

Permanent link to this document: $h$ htp://doi.org/10.17261/Pressacademia.2020.1300

Copyright: Published by PressAcademia and limited licensed re-use rights only.

\section{ABSTRACT}

Objective - The aim of this study is to determine the importance of foreign exchange inflow by examining the relationship between exchange rate and number of tourists with an econometric analysis. The effect of changing exchange rates on the number of tourists coming to Turkey, and whether the expenditures of the incoming tourists has an impact on the exchange rates is determined with an empirical analysis.

Methodology - Granger Causality Tests and the econometric model of Toda and Yamamoto were used in the study to analyze the relationship between tourist number and exchange rate. In addition, Augmented Dickey-Fuller (ADF) unit root test was also employed to determine the order stationarity of variables.

Findings - The study found a unilateral causality relationship between the number of tourists and the exchange rate. At this point, there is an unilateral causality relationship from the exchange rate to the number of tourists. While the exchange rate affects the number of tourists, the number of tourists does not affect the exchange rate.

Conclusion- In conclusion, it was stated with an econometric analysis that fluctuations in the exchange rate affect the number of tourists coming to Turkey and, the economic activities of tourists coming to Turkey do not affect the exchange rates.

Keywords: Tourism, tourist, exchange rate, Toda and Yamamoto Econometric model, VAR analysis. JEL Codes: EOO, F00, Z30

\section{INTRODUCTION}

With the globalization trend that have had an enormous impact on the whole world since the 1980s, the geographical boundaries have lost their importance. The rapid development in mass media and innovations such as smartphones, internet, satellite connections, fiber optic cables, etc. have caused geographical boundaries to lose their importance. The increase in mobilization between people as well as objects is a natural result of this process. Exploring the world which has become a global village, journeys to unknown places, and transportation to popular areas of interest and curiosity and has become easier.

The tourism sector seems to never lose its popularity in the world economy. On the contrary it gradually increases its importance over time. The world economy is based mainly on the service sector. Tourism is one of the most important sub-components of the service sector. Tourism sector, which plays an important role in the growth and development of countries, is also called 'chimney-free industry'.

Countries with archaeological, cultural, historical and natural beauties combine this advantage with the elements of 'tourism demand' and increase tourism profits. The profit of capital, combined with the labor-intensive service sector, bring about both capital inflow and a rise in employment levels in countries. (Şen \& Şit, 2015:6752). The 'foreign exchange-earning' feature of the tourism sector is quite remarkable. The tourism sector stands out as a vital source of foreign exchange, especially in achieving the balance of foreign trade in developing countries. (Uğuz and Topbaş, 2011: 2) 
A competitive strategy based on factor costs and price competition is being pursued in the tourism sector, which is one of the subcomponents of the service sector in Turkey. This strategy also makes exchange rate shocks created by fluctuations in foreign exchange markets, critical for the sector. Foreign currency volatility compared to other sectors is affecting the tourism sector rapidly. Terrorism, pandemic diseases, natural disasters, internal turmoil and political turmoil, which negatively affect tourism demand, stand out as 'sources of shock'.

Economic shocks, on the other hand, find themselves a new area of discussion in the literature. Some of these economic shocks occur as a result of developments such as fluctuations in oil prices and exchange rate shocks. For the tourism sector, which attracts fixed capital investments that can be considered risky, movements in exchange rates are perhaps one of the most important topics to follow.

The effect of any development in foreign exchange rates on Turkish tourism depends on the competitiveness of Turkish tourism in the world. The increase in the demand for Turkish tourism and an increase in the number of foreigners entering the country in response to any decrease in the exchange rate shows that, Turkish tourism has the quality to offer world-class service in response to this demand.

As tourism goods and services will become relatively cheap when the exchange rate rises, the increase in demand is expected to reflect positively on the country's tourism revenues. Otherwise, the country's tourism revenues fall into a downward trend. Therefore, the relationship of tourism revenues with the real exchange rate is of interest to researchers and policy makers. In this study, firstly the concepts of tourism sector and revenues, exchange rate and economic shock, secondly the relationship between the tourism sector, the number of incoming tourists and exchange rates were explained with a literature review. Finally, the relationship between the number of tourists coming to Turkey and the exchange rates was tested with Toda-Yamamato causality analysis with annual data covering the period of 1985-2019.

\section{LITERATURE REVIEW}

When studies evaluated within the scope of the literature survey are examined, it can be seen the relationship between exchange rate and tourism income is discussed within the framework of different variables and models. In this context, dependent variables of models are generally identified as tourism revenues, while it is shown that independent variables differ, and in addition to the real exchange rate; number of tourists, hotel prices, real GDP, world income and investment in tourism variables are also used. The number of studies examining the relationship between tourism revenues and economic growth is quite high. In his study, Crouch (1994) stated that the exchange rate has a key role in predicting tourism demand.

In a study on Singapore, conducted by Toh and Khan (1997), it was revealed that changes in exchange rate and tourist income, expressed $94 \%$ of the number of incoming tourists. Webber (2001) analyzed the relationship between Australian Tourism and the exchange rate by examining the quarterly data between 1983 and 1997 with Johansen and Granger Analyses, and concluded that changes in the exchange rate explained tourism demands by half. Dritsakis (2004) detected a strong Granger causality relationship between tourism revenues and the real exchange rate in Greece, with quarterly data from 1960-2000. Patsoaritis et al (2005) examined Greek tourism through regression analysis and found a strong correlation between tourism earnings and the real exchange rate. Eugenio-Martin and Morales (2004) found a weak relationship between exchange rate, tourism earnings and purchasing power parity after conducting Panel Data Analysis.

Employing ARDL analysis, Mervar and Payne (2007) found the impact of the exchange rate on demand for Croatian tourism to be weak in their study which covers the years 1994-2004.

In the framework of a reverse causality relationship, Narayan (2004) concluded that an increase of a country's currency against other country currencies contributes to the development of tourism along with wage increases.

Demirel et al. (2008) did not find a significant correlation between changes in exchange rates and tourist numbers in their studies. For tourists coming to Turkey from countries such as France, Germany, USA and UK, the exchange rate does not stand out as a meaningful variable.

In a study conducted by Sivri (2010), the number of tourists who came to Turkey between 1963-2008, their expenditures and the stagnation of tourist expenditures per capita was examined. Zivot-Andrews and Lee-Strazicich tests were employed and it was concluded that the series were stationary.

In his study, Belloumi (2010) examined Tunisia's data from 1970-2007 with the method of Cointegration and Granger causation; and concluded that there was a long-term relationship between the real exchange rate and tourism revenues and growth variables. 
In his study, Ghartey (2010) examined Jamaica's data from 1963-2008 using the method of Cointegration, Granger causation and $\mathrm{ADL}$ model. As a result of the study, there is a unilateral causality from long-term tourist revenues towards the exchange rate variable. There is no causality from economic growth to the exchange rate variable.

Mahmoudina et al. (2011) examined the relationships between economic growth and tourism revenues in Mena countries (19952007). As a result of their research, they found that there was a bilateral causality relationship between tourism revenues and economic growth in the short and long term. In addition, it was determined that there was a unilateral causality relationship from exchange rate to economic growth and from exchange rate to tourism revenues.

In their study, which employed cointegration and EGARCH models, Uğuz and Topbaş (2011) concluded that there was a statistically significant long-term relationship between the exchange rate, tourism demand and exchange rate volatility variables in the data of the years between 1990 and 2010 in Turkey.

Erkan et al. (2013) examined the relationship between tourism revenues and number of tourists in Turkey between 2005-2012 with VAR analysis and Granger causality test. As a result of their research, they concluded that there is a bilateral causal relationship between tourism revenues and the number of tourists in Turkey and that the real exchange rate does not have any effect on tourism revenues.

In his study, Tang (2013) investigated the relationship between tourism revenues and real income in Malaysia between 1974-2009 by using the Granger causality test. As a result of his research, he concluded that while the existence of a causal relationship between tourism revenues and real income could not be determined in the short term, there was no bi-directional causal relationship in the long term.

In their study, Jayat \& Hilake (2013) examined Sri Lanka's data between 1967 and 2011 with the method of Cointegration and Granger causation, and concluded that in the long term, there was a causality relationship between real GDP, international tourism income and real exchange rate. The results of the analysis support tourism-based growth. There is a unilateral causality relationship from tourist incomes towards economic growth.

Kılıç \& Bayar (2014) examined the relationship between real exchange rate, tourism revenues and investments in Turkey between 1994-2013. As a result of their research, they concluded that there is a long-term positive relationship between real exchange rate, tourism revenues and investments.

In their study, which employs Frequency Distribution and Bootsrap based Toda Yamamoto Causality method, Şen \& Şit (2015) concluded that between 2000 and 2012, the real exchange rate in Turkey had an effect on Turkey's tourism revenues, and tourism revenues affected the real exchange rate.

Using the data from Andalusia, Spain between 2005 and 2012 with the Multiple Regression analysis and Least Squares method, Nasir et al. (2015), concluded that the real exchange rate, the number of international tourists, hotel prices and the number of star hotels are important factors affecting tourism revenues.

In his study, Koyuncu (2015) tested the data between 1980 and 2014 of Turkey with the Granger causality method. The study revealed that there is a unilateral causality relationship between tourism income and current account deficit, unilateral relationship between growth and tourism income, bilateral relationship between growth and tourism income, and unilateral causality relationship between tourism income and exchange rate.

In their study, Barati and Ranjbar (2016) found that real national income and exchange rate coefficients had a positive relationship with tourism income in Latin America, Southeast Asia and Iran (1995-2011).

\section{TOURISM AND TOURISM POTENTIAL OF TURKEY WITH ITS FOREIGN EXCHANGE-EARNING FEATURE}

Today, the tourism sector is one of the leading income-generating factors in the world economy. Tourism income is too important for developing countries to ignore because of the positive economic effects it creates on the macroeconomic performance of countries such as creating jobs, providing foreign currency, and becoming a source of income for the government. (Değer,2006: 7).

Large amounts of investments make tourism a thriving sector. Tourism is regarded as one of the most important service sectors that enables a country to gain profit in economic, social and cultural areas. Therefore, the developed and developing countries with tourism potential, especially with the emphasis on international tourism activities, aim to raise the level of welfare both to accelerate their economic development and to spread revenue to the base of population in their countries (Aktaş, Kaplan and Kocaman, 2013: 755). 
Tourism income is included in the international services section of the current account and is an important income item for countries. Thanks to this feature, tourism income contributes to the growth of national income and the development of countries. Tourism, which is considered as an important source of income, has great importance in terms of foreign exchange revenues that it provides to countries and its contribution to financing the foreign and internal budget deficits of countries. On the other hand, it has important effects in reducing the burden of unemployment problem by creating employment opportunities. Tourism activities show an increasing rate of development in the world economy.

Tourism income also facilitates convergence between countries by contributing to its distribution from rich countries to poorer countries, from developed to developing and underdeveloped countries. In this way, tourism also helps regional development and allows reducing regional economic disparities. Therefore, the investments, which will be made in the tourism sector, will have a positive impact on the progress of the underdeveloped regions. (Bahar and Bozkurt, 2010: 255).

The service sector is a labor-intensive sector that includes tourism. In developing countries such as Turkey, where capital is insufficient but labor is intensive, the growth of the tourism sector is viewed as an opportunity to contribute to the increase of the national income of the country. These labor-intensive countries increase their employment levels and thus their national income by providing more foreign exchange inputs to their countries through the growth of the tourism sector (Yamak, Tanriöver and Güneysu, 2012: 206).

On the other hand, other sectors with which the tourism sector is connected can increase their production and thus their employment depending on the development of tourism. In this context, the development of tourism sector in developing countries creates growth in agriculture, industry, trade and services sectors, encouraging the increase of the country's production.

Especially after 1980, the tourism sector in Turkey experienced a great surge and today it has become one of the indispensable cornerstones of the country's development. This rapid rise of tourism in the Turkish economy undoubtedly has a very important place in the investment incentives and financial support, which was provided to the sectors by the "Tourism Incentive Law" No. 2634, which was enacted in 1982.

Due to Turkey's geographical, historical and cultural resources, Turkey is an attractive touristic center with extensive amenities such as health tourism, thermal tourism, cultural tourism, adventure tourism, golf tourism, religious tourism, congress tourism and winter tourism in addition to sun-sea-sand tourism what we call the classic holiday. With the worldview changing in parallel with the social and economic developments in developed countries, the importance attached to the lifestyle and life quality is both increasing and differentiating.

The use of natural resources is increasingly preferred in protecting human health and maintaining a healthy life. At this point, Turkey has the potential to be very ambitious in the development of modern health and thermal tourism with its traditional hot springs and Turkish baths. Turkey is among the most preferred countries in the world for offering quality and economical prices in healthcare services. In addition, its proximity to European countries, its easy access to the major cities of the world and its abundance of conference facilities, its first class location for meetings and congresses, enhance congress tourism in Turkey.

Thanks to its geographical structure, vegetation, suitable climatic features, outstanding landscape values and rural lifestyle with an emphasis on traditional values, Turkey is extremely suitable for adventure tourism, hunting tourism, winter tourism, the sports of mountaineering and speleology. For the development of religious tourism of the three Abrahamic religions -Islam, Christianity, Judaism, it is aimed to increase the number of visitors with the improvement of the important extant pilgrimage centers by considering aspects such as the landscaping, lighting, transportation, etc. and by promoting (Republic of Turkey Ministry of Culture and Tourism, 2014).

Turkey is a very rich country in terms of alternative tourism opportunities, which can be sustained both in summer and winter months. However, since tourism has been viewed only as a foreign exchange generating element in an unplanned development for years, mass tourism, that target sea-sand-sun, has been highlighted in the areas of promotion, marketing, investment and encouragement. Alternative tourism opportunities have been ignored. Turkey's historical and cultural advantages and unique natural beauties have been forgotten all over the world. The Ministry of Culture and Tourism has determined the targets to realize in the tourism sector with the "Tourism Strategy of Turkey (2023)".

With this strategy, Turkey will expand the tourism season throughout the year by developing alternative tourism opportunities as well as coastal tourism. Thus, it is aimed to increase the share of international tourism revenue. 


\section{METHODOLOGY AND DATA}

In this part of the study, the relationship between the number of tourists (TOUR) and the exchange rate (ER) was examined empirically. Depending on the availability of the data, study used annual data which covers the period of 1985-2019. The data were obtained from the tourism statistics of the Central Bank of the Republic of Turkey, TÜiK and TÜRSAB. Finally, in empirical analysis, the logarithm of variables was taken.

In this study, causality analysis proposed by Toda and Yamamoto (1995) was used to examine the relationship between exchange rate and number of tourists. The advantage of this method developed by Toda and Yamamoto (1995) is that it enables accessing to causality findings through the VAR model independently of the inter-series cointegrated relationship.

In the Toda-Yamamoto causality test, time series form a VAR model using level values of numerous levels - it does not matter which level- of order stationarity. In this test, which consists of two stages, firstly the optimal delay length is determined and the maximum degree of integration (dmax) is determined for the series that are subject to application. Determining the appropriate delay length for the VAR model is carried out using criteria such as Akaike and Hannan-Quinn. Thus, the augmented VAR model which includes the delay length of $\mathrm{K}+\mathrm{dmax}$ is estimated with the detection of $\mathrm{k}$, the optimal delay length with dmax, the maximum degree of integration. In the second phase, Wald tests are applied to the k delayed VAR coefficient Matrix, hence Granger causality-related inferences can be made.

Another advantage of this method proposed by Toda Yamamoto is that it allows causality inferences based on the VAR model regardless of whether the series are cointegrated or not. In addition, the fact that this approach does not require the use of some pre-tests, which are necessary for unit root tests, also makes the Toda Yamamato test more preferable.

On the procedural side of the Toda Yamamoto test, which can be applied to the level values of the series, an improved Wald test (MWALD), which applies restriction tests to the parameters of K-delayed VAR model is used. The first step of this two-step procedure is to determine the optimal length of k delay and the maximum degree of integration (dmax) for the series in the system. Criteria such as Akaike and Hannan-Quinn can be used to determine the appropriate delay length for the VAR model. With the determination of optimal delay length $(k)$ and maximum degree of integration (dmax), an improved VAR model containing a total delay length of $k+d m a x$ can be estimated. The second step of the procedure is performed by applying Wald tests to the VAR coefficient matrix with a delay length of $k$, which has been obtained to make inferences based on Granger causality.

\section{EMPIRICAL RESULTS}

In addition, firstly Augmented Dickey-Fuller (ADF) unit root test was also employed to determine the order stationarity of variables. The results of ADF unit root tests applied to the levels and first differences of variables are presented in the table.

Table 1: ADF Unit Root Test Results of the Levels and Differences of Variables

\begin{tabular}{ccc}
\hline & Augmented Dickey-Fuller (ADF) unit Root Test & t-statistic \\
\hline Variables & Delay Length & -0.74594 \\
MIN & 0 & -1.96657 \\
TOUR & 3 & $-5.29151^{*}$ \\
$\Delta$ MIN & 0 & $-4.57305^{*}$ \\
\hline TOUR & 3 & -50 \\
\hline \hline
\end{tabular}

Notes: The symbol of ${ }^{*}$ shows that the existence of the unit root with the zero hypothesis at the level of $5 \%$ significance is rejected. Delay lengths were determined using the Akaike Information Criterion (AIC). The symbol of " $\Delta$ " shows that the first level of difference of series is taken.

Firstly, expanded Dickey-Fuller (ADF) and Phillips-Perron (PP) unit root tests were used to determine the stasis order of variables during the investigation of the relationship between variables, with causality analysis developed by Toda and Yamamoto (1995). According to the results of the ADF unit root test, shown in Table 1, the exchange rate and number of tourists' variables are firstorder stationary variables. The models established for the Toda-Yamamoto causality test adapted to the study are as follows: 


$$
\begin{aligned}
& D K_{t}=\alpha_{1}+\sum_{i=1}^{k+d \max } \beta_{1 i} T U R_{t-i}+\sum_{i=1}^{k+d \max } \theta_{1 i} D K_{t-i}+\varepsilon_{1 t} \\
& T U R=\alpha_{2}+\sum_{i=1}^{k+d \max } \beta_{2 i} D K_{t-i}+\sum_{i=1}^{k+d \max } \theta_{2 i} T U R_{t-i}+\varepsilon_{2 t}
\end{aligned}
$$

Accordingly, $k$ was designated as " 1 " according to the VAR model, dmax as " 1 ", and the augmented VAR(2) model was estimated by the seemingly unrelated regression method. The causality analysis results obtained by this model are shown in Table 2 .

Table 2: Toda-Yamamoto Causation Analysis Results

\begin{tabular}{ccc}
\hline Zero Hypothesis & Delay Length & MWWALD Statistic \\
\hline TOUR $f$ MIN & 2 & 1.25292 \\
$M I N+T O U R$ & 2 & $7.07020^{*}$ \\
\hline \hline
\end{tabular}

The symbol of * shows the rejection of the zero hypothesis at $5 \%$ significance level.

According to the results in Table 2, a unilateral causality relationship was found between the number of tourists and the exchange rate. Accordingly, there is a unilateral causality relationship from the exchange rate to the number of tourists. While the exchange rate affects the number of tourists, the number of tourists does not affect the exchange rate.

\section{CONCLUSION}

Tourism sector, which is one of the most important sub-sectors of the service sector, increases its importance in the world as a sector that increases employment in addition to the positive externalities it provides to the manufacturing industry, agriculture and other sectors. Especially in the post-1980 period, the importance of the tourism sector in Turkey has been increasing with each passing day.

Tourism contributes to Turkey's integration into the global economy, as well as being a sector that provides currency to Turkey. There is a significant competition in terms of tourism sector in the world. Local, global, socio-economical and socio-cultural developments effect immensely the conduct of tourism activities. Therefore, tourism industry has become a global concept.

In the face of the exchange rate changes and/or uncertainties of the process of price-based competition in the Turkish tourism sector, there is an impact on tourism demand. In theory, it is expected that a positive shock in the exchange rate will reduce the prices of tourism services in Turkey, in terms of said exchange rate type.

On the other hand, in the event of a negative shock in the exchange rate, the prices of tourism services in the country will rise in terms of the said exchange rate, and since the domestic currency will gain value against the foreign exchange, it is expected to have a negative effect on the tourism demand shock.

In this study, the effect of exchange rate changes on the number of tourists coming to Turkey was examined. The findings have shown that there is a unilateral causality relationship where the number of tourists coming to Turkey does not affect the exchange rates but the exchange rate triggers the number of tourists. It is also understood that tourism is still considered as a luxury, since it is heavily influenced by changes in consumer incomes.

For Turkey, the exchange rate has been determined to be an important variable for those who prefer the destination. At this point, it was shown that the fact that Turkey has a more suitable touristic product price than the European countries with which it competes against, has positively affected the tourism demand in the long term.

Holiday sales directed at domestic tourists are negatively affected by the rising prices and the depreciation of the Turkish Lira. In terms of foreign tourists, the rise in the value of the dollar and the euro against the Turkish Lira allows more tourists to come to our country. In order to achieve the objective of spending per capita on foreign currency basis in tourism income, it is necessary to attract tourists with high-income to our country and also to invest in environment and smart urbanism in tourism destinations.

The recent increase in exchange rates is expected to affect tourism in two ways. Firstly, with these exchange rate increases, the number of visitors is foreseen to increase as Turkey becomes slightly cheaper for foreigners. Secondly, it is estimated that there 
may be a slowdown in foreign tourism due to the increase in foreign exchange rates making it more expensive for Turks, and that some shifts in domestic tourism may be experienced from there.

Turkey should increase its share of world tourism revenues which excess $\$ 1$ trillion. For tourism, which is under the influence of many internal and external factors due to its structure, emergency response plans can be prepared which can be implemented in extraordinary situations and which take into account a large number of possibilities. Additionally, if the continuation of a healthy cooperation of industry representatives and policy makers, stable continuation of structural reforms and arrangements for tourism, actualizing productivity-enhancing innovations, development of alternative tourism types by diversifying tourism services such as winter tourism, health tourism, nature tourism, etc., and updating tourism policies in accordance with the current conditions can be achieved, then Turkey will be able to rise up in the world tourism league and increase its share.

\section{REFERENCES}

Aktaş, A. Rıza, Kaplan, F. ve Kocaman, S. (2013). “Turizm ile Ekonomik Büyüme Arasındaki İlişki: Akdeniz Ülkeleri Üzerine Bir Panel Veri Analizi”, International Conference on Eurasian Economies, p.755-760.

Bahar, O. ve Bozkurt, K. (2010). "Gelişmekte Olan Ülkelerde Turizm-Ekonomik Büyüme ilişkisi: Dinamik Panel Veri Analizi”, Anatolia: Turizm Araştırmaları Dergisi, 21,(2), (Güz), s.255-265.

Barati E. ve H. Ranjbar (2016). Granger causality and dynamic relationship between the actual values of receipt derived from tourism, national income and exchange tares in selected countries in selected countries with tourist attraction. International business management, 10 (16), 33893395.

Belloumi M. (2010), "The Relationship between Tourism Receipt, Real Effective Exchange Rate and Economic Growth in Tunisia”, International Journal of Tourism Research,12(5):550 - 560

Değer, M. Kemal (2006). “Turizme ve İhracata Dayalı Büyüme: 1980-2005 Türkiye Deneyimi”, Atatürk Üniversitesi, iktisadi ve Idari Bilimler Dergisi, 20, s.68-86.

Demirel, B., Bozdağ, E. G. ve İnci, A. G. (2020, June 5). Döviz Kurlarındaki Dalgalanmaların Gelen Turist Sayısına Etkisi: Türkiye Örneği. Retrieved from http://www.deu.edu.tr/userweb/iibf kongre/dosyalar/demirel.pdf.

Dritsakis, N. (2004), Tourism as a Long-run Economic Growth Factor: an Empirical Investigation for Greece using Causality Analysis. Tourism Economics, 10, 305-316.

Erkan B., Kara, O. ve Harbalıoğlu, M. (2013). Türkiye'de Turizm Gelirlerinin Belirleyicileri. Akademik bakış dergisi, S. 39, 1-20.

Eugenio-Martin ve Morales (2004).Tourism and Economic Growth in Latin American Countries: A Panel Data Approach, Nota Di Lavoro 26.

Ghartey E. E. (2010), "Tourism, "Economic Growth and Monetary Policy in Jamaica",11th Annual SALISES 2010 Conference in Port of Spain, Trinidad-Tobago, 24-26 March, 1-25.

Jayathilake Bandula P. M. (2013), "Determinants of Demand for International Tourism in Sri Lanka: An Econometric Evaluation", International Journal of Business, Economics and Law, vol. 2, issue. 2, 22-27.

Kılıç, C. ve Bayar, Y. (2014). Effects of Real exchange rate volatility on tourism receipts and expenditures in Turkey. Advances in management \& applied economics, Vol. 4, No. 1. 89-101.

Koyuncu F. T. (2015), “Turizm Gelirinin Türkiye'nin Makro Ekonomik Performansına Katkısı: Ekonometrik Bir Çözümleme”, Uluslararası Sosyal Araştırmalar Dergisi, cilt. 8, sayı. 38, 959-968.

Mahmoudinia, D., Soderjani, E. S. \& Pourshahabi, F. (2011). Economic growth, tourism receipts and exchange rate in MENA zone: Using panel causality technique. Iranian economic review, vol. 15, no.29, 129-146.

Mervar, A. ve Payne, J. (2007). Analysis of Foreign Tourism Demand for Croatian Destinations: Long-Run Elasticity Estimates, Tourism Economics, 13: 407-20.

Narayan, P.K. (2004). Economic Impact of Tourism on Fiji's Economy: Empirical Evidence from the Computable General Equilibrium Model. Tourism Economics, 10:419-33.

Nasir A. M., J. WU ve J. C. Guerrero (2015), "Economic Growth, Exchange Rate and Constrained Competiveness of the Tourism Sector in Andalucia", International Journal of Management and Economics, No. 48, 84-100.

Patsouratis, V. Frangouli, Z. ve Anastasopoulos G. (2005). Competition in Tourism among the Mediterranean Countries. Applied Economics, 37:1865-70.

Sivri, U. (2010). Şokların Yabancı Ziyaretçi Sayısı ve Yabancı Ziyaretçi Harcamaları Üzerindeki Etkisi Kalııı Mıdır? TiSK Akademi Dergisi, 5 (10), 220237. 
Crouch, G. I. (1994). The Study of International Tourism Demand: A Review of Findings. Journal of Travel Research, 12-23.

ŞEN A. ve ŞiT M. (2015). Reel Döviz Kurunun Türkiye’nin Turizm Gelirleri Üzerindeki Etkisinin Amprik Analizi”, Journal of Yaşar University, 10/40, 6752-6762.

Tang, C.F. (2011) Is the tourism-led growth hypothesis valid for Malaysia? A view from disaggregated tourism markets. International journal of tourism research, 13, pp. 97-101.

Toda, H. Y.; Yamamoto, T., (1995). Statistical Inference in Vector Autoregression with Possibly Integrated Processes. Journal of Econometrics, Volume 66: 225-250

Toh, R. S., H. Khan, and F. T. Ng (1997). Prospects for the Tourism Industry in Singapore: A Regression Model. Cornell HRA Quarterly, $38:$ 80-87.

Uğuz S. Ç. ve Topbaş F. (2011). Döviz Kuru Oynaklığı Turizm Talebi İlişkisi, Paper Presented at EconAnadolu 2011:Anadolu International Conference in Economics II June 15-17:1-11.

Webber A. (2001). Exchange Rate Votality and Coentegration in Tourism Demand. Journal of Travel Research, $39: 398$.

Türkiye Cumhuriyeti Kültür ve Turizm Bakanlığı, (2014). Retrieved from http://www.kultur.gov.tr, Date of Access: 18.07.2020. 